\title{
Suomen elintarvikeketjun hinnanmuodostus kansainvälisessä vertailussa
}

\author{
Olavi Rantala
}

ETLA, Lönnrotinkatu 4 B 00120 Helsinki, Olavi.Rantala@etla.fi

\section{Tiivistelmä}

Elinkeinoelämän Tutkimuslaitoksen tutkimuksessa "Elintarvikkeiden hinnanmuodostus ja markkinoiden toimivuus" (ETLA, Keskusteluaiheita No. 1209, 2010) käsiteltiin muun muassa Suomen elintarvikeketjun hinnanmuodostusta vertailemalla Suomen, EU-alueen ja Yhdysvaltojen elintarvikeketjujen kilpailua ja kilpailukykyä.

Kansainvälisten ostovoimapariteettitilastojen mukaan elintarvikkeet olivat vuonna 2005 Suomessa 21 prosenttia kalliimpia kuin EU-maissa keskimäärin ja 16 prosenttia kalliimpia kuin OECD-maissa keskimäärin. Vuonna 2010 Suomen hintaero EU-alueeseen oli 11 prosenttia.

Elintarvikkeiden kuluttajahintoihin vaikuttavat elintarvikkeiden arvonlisäverotus sekä elintarvikeketjun toimialojen tuottajahinnat. Tuottajahintoihin vaikuttavat puolestaan kilpailu ja tuotannon yksikkökustannukset elintarvikeketjun toimialoilla. Tutkimuksen tavoitteena oli selvittää, missä määrin elintarvikkeiden kuluttajahintojen korkeus Suomessa johtuu elintarvikkeiden arvonlisäverotuksen kireydestä ja missä määrin se johtuu elintarvikeketjun kilpailun tai kustannuskilpailukyvyn puutteista suhteessa vertailumaihin.

Suomessa elintarvikkeiden arvonlisäverotus on ollut EU-maiden kireimpiä. Arvonlisäverotuksen kireys on siis yksi syy Suomen kansainvälisesti vertaillen korkeaan elintarvikkeiden kuluttajahintatasoon.

Arvonlisäverotuksen ohella Suomen elintarvikekulutuksen kansainvälisesti vertaillen korkean hintatason syyksi on arveltu vähäistä kilpailua elintarvikeketjussa. Tutkimuksessa käsiteltiin kysymystä Suomen ja muiden maiden elintarvikekulutuksen hintaerojen syistä tarkastelemalla elintarvikeketjun toimialojen, eli maatalouden (ml. kalastus), elintarviketeollisuuden ja kaupan kilpailun ja kilpailukyvyn osuutta Suomen, EU-alueen ja Yhdysvaltojen elintarvikekulutuksen hintaerojen selittäjinä.

Selvityksen perusteella elintarvikeketjun tuottajahintoja määrittävä kilpailullisuus on Suomen maataloudessa, elintarviketeollisuudessa ja kaupassa hinta-kustannusmarginaalilla mitattuna suunnilleen vertailumaiden tasolla. Suomen elintarvikekulutuksen hintatason korkeutta ei siten selitä Suomen elintarvikeketjun kilpailun puute suhteessa vertailumaihin. Kilpailun puutteen sijasta Suomen elintarvikekulutuksen hintatason korkeutta suhteessa vertailumaihin selittää pikemminkin kilpailukyvyn puute, eli Suomen elintarvikeketjun korkea kustannustaso etenkin uusien EU-maiden ja Yhdysvaltojen kustannustasoon verrattuna. Länsi-Euroopan vanhoihin EU-maihin verrattuna kilpailukykyongelmaa on lähinnä vain maataloudessa.

Keskeinen syy Suomen maatalouden kilpailukykyongelmaan on vertailumaita heikompi tuottavuus, jonka taustalla on muun muassa se, että meillä maataloutta joudutaan harjoittamaan huonommissa luonnonoloissa kuin vertailumaissa. Sen sijaan elintarviketeollisuuden ja kaupan tuottavuus on Suomessa kansainvälisesti vertaillen melko hyvällä tasolla ja keskeinen selittäjä sille, että Suomen elintarviketeollisuus ja kauppa ovat tuottajahinnoilla ja tuotannon yksikkökustannuksilla tarkastellen melko kilpailukykyisiä suhteessa läntisiin teollisuusmaihin.

Asiasanat: Elintarvikkeiden hinnat, elintarvikeketju, kilpailu, kilpailukyky 


\section{Johdanto}

Elinkeinoelämän Tutkimuslaitoksen tutkimuksessa "Elintarvikkeiden hinnanmuodostus ja markkinoiden toimivuus" (Kotilainen, Koski, Mankinen \& Rantala, ETLA, 2010) tutkittiin elintarvikeketjun hinnanmuodostusta, kilpailua ja kilpailukykyä kansainvälisellä vertailulla, jossa Suomen vertailukohteita olivat Länsi-Euroopan ns. vanhojen EU-maiden (EU-15), uusien EU-maiden ja Yhdysvaltojen elintarvikeketjut. Hinnanmuodostuksen kansainvälisen vertailun lisäksi elintarvikeketjun keskittyneisyyttä, kilpailua, sopimuskäytäntöjä ja pienten tuottajien asemaa tarkasteltiin yksityiskohtaisemmin Suomen osalta.

EU:n tilastoviraston Eurostatin ja OECD:n toteuttaman ostovoimapariteettivertailun mukaan elintarvikkeet olivat vuonna 2005 Suomessa 21 prosenttia kalliimpia kuin EU-maissa keskimäärin ja 16 prosenttia kalliimpia kuin OECD-maissa keskimäärin. Elintarvikkeiden kuluttajahinnoissa on hyvin suuria eroja eri maiden välillä. Vuonna 2005 elintarvikkeet olivat Suomessa 35 prosenttia kalliimpia kuin Yhdysvalloissa, mutta lähes 40 prosenttia halvempia kuin Japanissa. Sittemmin mm. valuuttakurssi- ja arvonlisäveromuutokset ovat muuttaneet maiden suhteellisia hintoja niin, että elintarvikkeet olivat Suomessa vuonna 2010 enää 11 prosenttia kalliimpia kuin EU-alueella keskimäärin.

Elintarvikkeiden kuluttajahintoihin vaikuttavat elintarvikkeiden arvonlisäverotus sekä elintarvikeketjun toimialojen tuottajahinnat. Elintarvikeketjun tuottajahintoja määrittävät puolestaan kilpailu ja tuotannon yksikkökustannukset elintarvikeketjun toimialoilla. Tutkimuksen keskeinen tavoite oli selvittää, missä määrin elintarvikkeiden kuluttajahintojen korkeus Suomessa johtuu elintarvikkeiden arvonlisäverotuksen kireydestä ja missä määrin se johtuu elintarvikeketjun kilpailun tai kustannuskilpailukyvyn puutteista suhteessa vertailumaihin. Arvonlisäverokantojen erojen vaikutus elintarvikkeiden hintaeroihin on siinä määrin selvä, että tutkimuksessa päähuomion saivat elintarvikeketjun kilpailullisuuden ja kilpailukyvyn erojen sekä elintarvikeketjun rakenne-erojen vaikutukset elintarvikkeiden perushinnan eroon Suomen ja vertailumaiden välillä.

\section{Aineisto}

ETLAn tutkimuksessa elintarvikkeiden kuluttajahintatason vertailu Suomen ja muiden maiden välillä perustui Eurostatin ja OECD:n ostovoimapariteettitutkimusten aineistoihin. Elintarvikeketjun toimialojen tuottajahintojen kansainvälinen vertailu perustui puolestaan tuottajahintapariteeteista tehtyihin laskelmiin, joita on käytetty muun muassa EU:n KLEMS-projektin tuottavuusvertailuissa (http://www.euklems.net/).

Suomen ja vertailumaiden elintarvikeketjun toimialojen kilpailullisuuden ja kilpailukyvyn mittaamiseen käytettiin kansantalouden tilinpidon aikasarja-aineistoa, joka saatiin pääosin EU:n KLEMS-projektissa kootusta tietokannasta. Elintarvikekaupasta ei ollut käytettävissä kansantalouden tilinpidon aineistoa, joten elintarvikekaupan kilpailullisuutta Suomessa ja muualla EU-alueella tarkasteltiin Eurostatin Structural Business Statistics -aineistosta laskettujen hinta-kustannusmarginaalien aikasarjoilla.

Suomen ja vertailumaiden kotitalouksien elintarvikekulutuskorin rakenne selvitettiin panostuotostilastoista. Tutkimuksen tekoajankohtana kattavin valikoima EU-maiden panos-tuotostilastoja oli saatavissa vuodelta 2000. Kansainvälisen vertailuun käytettiin lähinnä Eurostatin kokomamia vuoden 2000 panos-tuotostilastoja. Yhdysvaltojen ja muutamien EU-maiden tapauksessa käytettiin OECD:n kokoamia vuoden 2000 panos-tuotostilastoja.

\section{Tulokset}

\section{Suomen elintarvikeketjun kilpailullisuus ja kilpailukyky kansainvälisessä vertailussa}

Hinta-kustannusmarginaalilla mitattuna elintarvikeketjun tuottajahintoja määrittävä kilpailullisuus on Suomen maataloudessa, elintarviketeollisuudessa ja kaupassa suunnilleen vertailumaiden tasolla. Suomen elintarvikekulutuksen hintatason korkeutta ei siten selitä Suomen elintarvikeketjun kilpailun puute suhteessa vertailumaihin. Kilpailun puutteen sijasta Suomen elintarvikekulutuksen hintatason korkeutta suhteessa vertailumaihin selittää pikemminkin kilpailukyvyn puute, eli Suomen elintarvikeketjun korkea kustannustaso etenkin uusien EU-maiden ja Yhdysvaltojen kustannustasoon verrattuna. Länsi-Euroopan vanhoihin EU-maihin verrattuna kilpailukykyongelmaa on lähinnä vain maataloudessa.

Keskeinen syy Suomen maatalouden kilpailukykyongelmaan on vertailumaita heikompi tuottavuus, 
jonka taustalla on muun muassa se, että meillä maataloutta joudutaan harjoittamaan huonommissa luonnonoloissa kuin vertailumaissa. Tuottavuuden mataluus ei ole ongelma vain Suomen maataloudessa, vaan koko EU-alueen maataloudessa, jonka tuottavuus on huomattavasti Yhdysvaltojen maatalouden tuottavuutta heikompi. Uusissa EU-maissa maatalouden tuottavuus on vielä heikompi kuin EU15-alueella. Vuonna 2005 uusien EU-maiden maatalouden tuottavuus oli noin puolet Suomen ja vain noin kolmasosa EU15-alueen maatalouden tuottavuudesta. KLEMS-aineiston perusteella laskien OECD-alueella Australian maatalouden tuottavuus yltää Yhdysvaltojen maatalouden tuottavuuden tuntumaan. Sen sijaan Japanissa ja Etelä-Koreassa maatalouden tuottavuus on heikompi kuin Suomessa ja muualla EU-alueella. Maatalouden suuret tuottavuuserot kuvastavat paljolti skaalaetujen merkitystä maataloustuotannossa.

Elintarviketeollisuuden tuottavuus on Suomessa parempi kuin EU15-alueella keskimäärin ja melko lähellä Yhdysvaltojen tasoa. Suomessa elintarviketeollisuuden tuottavuus on kasvanut vahvemmin kuin vertailumaissa ja selittää sitä, että elintarviketeollisuuden kansainvälinen kustannuskilpailukyky on Suomessa parantunut huomattavasti 1990-luvulta lähtien. Suomen kaupan tuottavuus on kansainvälisesti vertaillen hyvällä tasolla ja keskeinen selittäjä sille, että Suomen kauppa on palveluiden hinnoilla ja tuotannon yksikkökustannuksilla tarkastellen melko kilpailukykyinen suhteessa läntisiin teollisuusmaihin.

\section{Kotitalouksien elintarvikekulutuskorin rakenne}

Kun lähdetään selvittämään eroja elintarvikkeiden kuluttajahinnoissa Suomen ja muiden maiden välillä, keskeinen kysymys on elintarvikeketjun tuottajahintojen vaikutus elintarvikekulutuksen perushintoihin. Tässä tarkastelussa tarvitaan tietoa elintarvikeketjun rakenteesta, eli painoista, joilla elintarvikeketjun toimialojen tuottajahinnat vaikuttavat elintarvikekulutuksen perushintaan Suomessa ja vertailumaissa.

Elintarvikeketjun toimialojen tuottajahintojen painot elintarvikekulutuksen perushinnassa voidaan laskea panos-tuotostilaston kuvaaman kotitalouksien kuluttamien elintarvikkeiden toimialoittaisen tarjontarakenteen perusteella. Suomesta ja useimmista tutkimuksen kansainvälisessä vertailussa mukana olleista EU-maista oli käytettävissä Eurostatin kokoamat panos-tuotostilastot. Kattavin valikoima EUmaiden panos-tuotostilastoja oli tutkimuksen tekoajankohtana saatavissa vuodelta 2000. Tästä syystä selvityksen kansainvälisen vertailuun käytettiin vuoden 2000 panos-tuotostilastoja. Tutkimukseen käytettiin ensisijaisesti Eurostatin aineistoa. Yhdysvaltojen ja muutamien EU-maiden osalta käytettiin OECD:n kokoamia vuoden 2000 panos-tuotostilastoja, jotka eivät ole toimialajaottelultaan aivan yhtä yksityiskohtaisia kuin Eurostatin kokoamat tilastot.

Julkaistuissa panos-tuotostauluissa kotitalouksien kulutusmenoja ei eritellä hyödykeryhmittäin. Elintarvikekulutuksen jakautumista elintarvikeketjun kotimaisille ja ulkomaisille tuottajatoimialoille ei siten saada suoraan panos-tuotostilastoista. Ongelmana on lähinnä kaupan osuuden arviointi. Kotitalouksien käyttämien elintarvikkeiden tarjontarakenne on kuitenkin siinä määrin yksinkertainen, että kaupan osuus elintarvikeketjussa voidaan laskea helposti jäännöseränä, kun kansantalouden tilinpidosta lasketaan elintarvikekulutusmenot perushintaan ja toisaalta panos-tuotostilastojen perusteella tiedetään kotitalouksien perushintaisen elintarvikekulutuksen jakautuminen kotimaisen ja ulkomaisen maatalouden, kalastuksen ja elintarviketeollisuuden toimialoille.

Kaupalla on Suomen elintarvikeketjussa suurempi paino kuin vertailualueilla. Panos-tuotostilastojen perusteella laskien Suomen kaupalla on Italian jälkeen toiseksi suurin paino EU-maiden elintarvikeketjuissa. Kaupan osuus on lähes samalla tasolla myös Tanskassa ja Hollannissa. Elintarviketeollisuuden osuus on Suomessa jonkin verran pienempi kuin vertailumaissa. Suomessa myös tuonnin osuus on vähäisempi kuin EU15-alueella keskimäärin. Yhdysvaltojen elintarvikeketjussa tuonnilla on hyvin vähäinen osuus ja elintarviketeollisuudella suuri osuus EU-maihin verrattuna.

Panos-tuotosaineiston pohjalta laskien elintarvikeketjun rakenne on Suomessa pysynyt melko vakaana ajassa (ETLA, 2010, liite 2). Lievää suhdannevaihtelua rakenteen kehityksessä näkyy, ei sen sijaan selviä trendinomaisia muutoksia. Tulos poikkeaa PTT:n eri menetelmällä laskemasta arviosta, jonka mukaan maatalouden osuus on viime vuosina miltei jatkuvasti pienentynyt ja kaupan osuus kasvanut (Arovuori, Karikallio \& Pyykkönen, 2011). 


\section{Elintarvikeketjun tuottajahinnat}

Elintarvikeketjun rakenteen ohella keskeisiä seikkoja elintarvikkeiden perushintojen erojen syiden erittelyssä ovat elintarvikeketjun toimialojen tuottajahintojen sekä niitä määrittävän kilpailun ja kilpailukyvyn erot Suomen ja vertailumaiden välillä. Ostovoimapariteettilaskelmien mukaisesti tuontihintojen voidaan olettaa olevan koko ajan pariteetissa siten, että kansainvälisen kaupan hinnat ovat samat kaikille maille (OECD \& Eurostat, 2004). Tällöin Suomen ja muiden maiden erot elintarvikekulutuksen perushinnoissa heijastavat eroja kunkin maan elintarvikeketjun kotimaisissa tuottajahinnoissa ja elintarvikeketjun rakenteissa.

ETLAn tutkimukseen Suomen ja vertailumaiden elintarvikeketjun toimialojen tuottajahinnat saatiin kansainvälisestä tuottajahintapariteettiaineistosta, jota on käytetty muun muassa EU:n KLEMStuottavuustutkimuksessa. Maatalouden tuottajahintatietojen pohjana on FAO:n aineisto ja teollisuuden tuottajahintatietojen pohjana EU:n Prodcom -aineisto (Timmer, Ypma \& van Ark, 2007). KLEMSprojektissa vuodelle 1997 lasketut suhteelliset tuottajahinnat ketjutettiin ETLAn tutkimuksessa elintarvikeketjun toimialojen kansallisin tuotoshinnoin ja valuuttakurssein vuoteen 2005.

Tämän aineiston mukaan maatalouden tuottajahinta on Suomessa korkeampi kuin EU-alueella ja Yhdysvalloissa. Keskeinen taustatekijä tässä on Suomen maatalouden kilpailukykyongelma. Maatalouden tuottajahinnat heijastuvat elintarviketeollisuuden tuottajahintoihin sillä painolla, jolla elintarviketeollisuus kussakin maassa käyttää tuotannon välituotepanoksina maatalouden tuotteita. Elintarviketeollisuuden tuottajahinta on Suomessa suunnilleen samalla tasolla kuin EU15-alueella keskimäärin, mutta korkeampi kuin muualla EU-alueella ja Yhdysvalloissa.

Suomen kaupan toimiala on palveluiden hinnoilla tarkastellen melko kilpailukykyinen suhteessa läntisiin teollisuusmaihin. Tukkukaupan tuottajahinta on Suomessa alempi kuin EU15-alueella keskimäärin ja vähittäiskaupan tuottajahinta on suunnilleen EU15-alueen keskitasoa. Uusissa EU-maissa kaupan tuottajahinnat ovat alempia kuin Suomessa. Myös Yhdysvalloissa kaupan tuottajahinta on jonkin verran alempi kuin Suomessa. Kaupan tuotoksen hintakomponentin arviointi on kuitenkin hankalampaa kuin muiden toimialojen tuottajahintojen laskenta (Timmer \& Ypma, 2006). Tämä epävarmuustekijä on otettava huomioon kaupan tuottajahintojen kansainvälisessä vertailussa.

\section{Elintarvikkeiden kansainvälisten kuluttajahintaerojen syiden erittely}

Elintarvikeketjun toimialojen tuottajahintojen ja elintarvikkeiden tuontihintojen vaikutusta elintarvikekulutuksen perushintaan voidaan tarkastella painottamalla elintarvikeketjun toimialojen tuottajahintojen ja tuontihintojen vaikutukset yhteen edellä kuvatuilla panos-tuotosaineistoista lasketuilla Suomen ja vertailumaiden elintarvikeketjun rakennepainoilla.

Tutkimuksessa todettiin ekonometrisen epätäydellisen kilpailun mukaista hinnoittelua testaavan mallin estimointitulosten perusteella, että elintarvikeketjun toimialojen tuottajahinnat määräytyvät lähinnä kotimaisten tuotantokustannusten perusteella. Tällä perusteella elintarvikeketjun kotimaisten toimialojen tuottajahintojen voidaan olettaa määräytyvän pelkästään toimialojen kotimaisista yksikkökustannuksista tuotoksen ja muuttuvien kustannusten pohjalta laskettavilla hintamarginaalikertoimilla. Vastaavasti vertailumaan elintarvikeketjun toimialojen tuottajahinnat määräytyvät toimialojen yksikkökustannuksista vertailumaan hintamarginaalikertoimilla.

Suomen elintarvikekulutuksen perushinta määräytyy panos-tuotostilastosta laskettavin kotitalouksien elintarvikekorin rakennepainoin elintarvikeketjun kotimaisten toimialojen tuottajahinnoista ja tuontihinnoista. Vertailumaan elintarvikekulutuksen perushinta määräytyy puolestaan vertailumaan elintarvikeketjun toimialoittaisten tuottajahintojen ja tuontihintojen painotettuna keskiarvona.

Tutkimuksessa osoitettiin, että kun elintarvikeketjun tuottajahinnat mallinnetaan määräytymään hintamarginaalikertoimilla tuotannon yksikkökustannuksista, Suomen ja vertailumaan elintarvikekulutuksen perushintojen ero voidaan dekomponoida toimialojen kilpailullisuuden eroista, toimialojen kilpailukyvyn eroista ja elintarvikeketjun rakenne-eroista johtuviin osatekijöihin.

Hintaero voidaan esittää kolmen osatekijän summana. Ensimmäinen tekijä mittaa Suomen ja vertailumaan elintarvikeketjujen kilpailullisuuseron vaikutusta elintarvikkeiden perushintojen eroon. Toinen tekijä mittaa Suomen ja vertailumaan elintarvikeketjujen kustannuskilpailukykyeron vaikutusta elintarvikkeiden hintaeroon. Kolmas tekijä mittaa Suomen ja vertailumaan elintarvikeketjujen rakenne-eron 
vaikutusta elintarvikkeiden hintaeroon. Oheinen taulukko kuvaa tällä tavoin laskettuja Suomen ja vertailumaiden elintarvikekulutuksen perushintojen eron osatekijöitä, eli elintarvikeketjun toimialojen kilpailullisuuserojen, kustannuserojen sekä elintarvikeketjun rakenne-erojen vaikutuksia hintaeroon.

Elintarvikeketjun rakennepainot, eli elintarvikeketjun toimialojen tuottajahintojen ja tuontihintojen painot kotitalouksien elintarvikekulutuksen perushinnassa perustuvat Suomen ja vertailualueiden osalta edellä kuvatulla tavalla vuoden 2000 panos-tuotostilastoihin. Elintarvikeketjun tuottajahintoina, kilpailullisuutta kuvaavina hintamarginaalikertoimina sekä kilpailukyvyn mittareina toimivina tuotannon yksikkökustannuksina käytetään elintarvikekulutuksen perushintoja vastaavasti vuodelle 2005 laskettuja lukuja. Kaupan hintamarginaalikertoimet perustuvat Suomen ja muiden EU-maiden osalta elintarvikekaupan ja Yhdysvaltojen osalta koko tukku- ja vähittäiskaupan kilpailutilanteeseen vuonna 2005.

Taulukossa on omalla rivillään esitetty tilastoero, joka jää kansainvälisen ostovoimapariteettivertailun pohjalta laskettujen elintarvikekulutuksen perushintojen sekä elintarvikeketjun tuottajahinnoista ja tuontihinnoista elintarvikeketjun rakennepainoin laskettujen perushintojen väliin. Tilastoero johtuu lähinnä siitä, että elintarvikekulutuksen hinnat ja elintarvikeketjun toimialojen tuottajahinnat ovat peräisin eri perustilastoista. Suomea, EU15-aluetta ja Yhdysvaltoja vertailtaessa tilastoerot eivät ole kovin suuria. Sen sijaan muutamissa uusissa EU-maissa Eurostatin ja OECD:n ostovoimapariteettivertailuun pohjautuvat elintarvikekulutuksen perushinnat ovat selvästi EU-alueen keskitasoa alhaisemmat, mutta kansainvälisen tuottajahintapariteettiaineiston pohjalta lasketut elintarvikeketjun toimialojen tuottajahinnat ovat monilta osin EU-alueen keskitasoa korkeampia. Taulukossa uusien EU-maiden elintarvikekulutuksen perushinnan ja elintarvikeketjun tuottajahinnoista lasketun hinnan epäsuhta heijastuu muun EU-alueen kohdalla näkyvään suureen tilastoeroon.

\section{Suomen elintarvikekulutuksen perushinnan ero EU-alueeseen ja Yhdysvaltoihin vuonna 2005}

\begin{tabular}{|c|c|c|c|c|}
\hline & & EU-15 & Muu EU & Yhdysvallat \\
\hline \multirow{4}{*}{$\begin{array}{l}\text { Kilpailun } \\
\text { puutteen } \\
\text { vaikutus }\end{array}$} & Kauppa & 1 & 2 & -1 \\
\hline & Elintarviketeollisuus & 0 & 0 & -1 \\
\hline & Maatalous & -1 & -1 & 0 \\
\hline & Yhteensä & 0 & 1 & -1 \\
\hline \multirow{4}{*}{$\begin{array}{l}\text { Kustannus- } \\
\text { eron } \\
\text { vaikutus }\end{array}$} & Kauppa & -7 & 12 & 6 \\
\hline & Elintarviketeollisuus & -1 & 15 & 5 \\
\hline & Maatalous & 3 & 5 & 5 \\
\hline & Yhteensä & -4 & 32 & 15 \\
\hline \multirow{5}{*}{$\begin{array}{l}\text { Elintarvike- } \\
\text { ketjun } \\
\text { rakenne-eron } \\
\text { vaikutus }\end{array}$} & Kauppa & 17 & 10 & 17 \\
\hline & Elintarviketeollisuus & -10 & -6 & -25 \\
\hline & Maatalous & 0 & 0 & 1 \\
\hline & Tuonti & -6 & -5 & 5 \\
\hline & Yhteensä & 2 & -1 & -1 \\
\hline \multirow{7}{*}{$\begin{array}{l}\text { Kokonais- } \\
\text { vaikutus }\end{array}$} & Kauppa & 12 & 25 & 22 \\
\hline & Elintarviketeollisuus & -10 & 9 & -21 \\
\hline & Maatalous & 2 & 4 & 6 \\
\hline & Tuonti & -6 & -5 & 5 \\
\hline & Tilastoero & 4 & 9 & 4 \\
\hline & Yhteensä & 2 & 42 & 17 \\
\hline & Perushinta, Suomi $=100$ & 98 & 58 & 83 \\
\hline
\end{tabular}

Taulukosta havaitaan, ettei Suomen elintarvikekulutuksen perushinnan korkeutta suhteessa vertailumaiden perushintoihin selitä Suomen elintarvikeketjun kilpailun puute suhteessa vertailumaihin. Kilpailun puutteen sijasta Suomen elintarvikekulutuksen perushinnan korkeutta selittää kilpailukyvyn puute, eli Suomen elintarvikeketjun korkea kustannustaso suhteessa uusiin EU-maihin ja Yhdysvaltoihin. EU15-alueeseen verrattuna kilpailukykyongelmaa on vain maataloudessa. Sen sijaan Suomen kauppa ja elintarviketeollisuus ovat EU15-alueeseen verrattuina sen verran kilpailukykyisiä, että elintarvikeketjun tuotantokustannusten eroista tulee kaiken kaikkiaan negatiivista vaikutusta elintarvikekulutuksen hintaeroon Suomen ja EU15-alueen välillä.

Suomen elintarvikekulutuksen perushinnan korkeus suhteessa vertailumaihin voisi selittyä osaltaan 
Suomen ja vertailumaiden elintarvikeketjujen rakenne-eroilla. Kaupalla on Suomen elintarvikeketjussa suurempi paino kuin vertailumaissa. Toisaalta elintarviketeollisuuden osuus on meillä kansainvälistä tasoa pienempi. Myös tuonnin osuus elintarvikeketjussa on Suomessa vähäisempi kuin EU-alueella keskimäärin. Yhdysvaltojen elintarvikeketjussa tuonnilla on hyvin vähäinen osuus ja elintarviketeollisuudella suuri osuus.

Taulukosta havaitaan, että elintarvikeketjun rakenne-erojen vaikutukset elintarvikekulutuksen perushintojen eroon Suomen ja vertailualueiden välillä nettoutuvat käytännössä lähes olemattomiksi. Johtopäätöksenä on näin ollen, että Suomen elintarvikekulutuksen korkeaa hintatasoa suhteessa vertailumaihin selittää pääosin Suomen elintarvikeketjun korkea kustannustaso ja arvonlisäverotuksen kireys. Vanhoihin EU-maihin hintaeroa syntyy lähinnä vain elintarvikkeiden arvonlisäverotuksesta.

\section{Elintarvikeketjun kustannusrakenne Suomessa ja vertailumaissa}

Panos-tuotostilastojen mukaan kaupalla on Suomen elintarvikeketjussa suurempi paino kuin vertailumaissa. Tutkimuksessa pyrittiin hakemaan mahdollisia syitä kaupan keskimääräistä suuremmalle osuudelle Suomen elintarvikeketjussa tarkastelemalla Suomen kaupan toimialan ja laajemmin muidenkin elintarvikeketjun toimialojen kustannusrakenteiden eroja suhteessa vertailumaihin vuoden 2000 panostuotostilastojen perusteella.

Kaupan kansainvälisesti vertaillen suurta osuutta Suomen elintarvikeketjussa saattaa osin selittää se, että kaupan kuljetustoimialalta ostamien kuljetuspalveluiden kustannusosuus on Suomessa suuri suhteessa vertailumaihin. Pitkistä kuljetusmatkoista ja osin kuljetustoimialan suurista yksikkökustannuksista johtuvat suuret kuljetuskustannukset voivat siis selittää kaupan keskimääräistä suurempaa osuutta Suomen elintarvikeketjussa. Lisäksi Suomen kaupan toimiala hoitaa itse joitakin toimintoja laajemmassa määrin kuin kauppa vertailumaissa. Panos-tuotostilastojen mukaan Suomen kaupan toimialalla kiinteistöpalveluja sekä tietojenkäsittely-, siivous- ym. palveluita on ulkoistettu huomattavasti vähemmän kuin vertailumaissa.

\section{Johtopäätökset}

Kansainvälisten ostovoimapariteettitilastojen mukaan elintarvikkeet ovat Suomessa olleet pitkään kalliimpia kuin EU-maissa ja OECD-maissa keskimäärin. Elintarvikkeiden kuluttajahintoihin vaikuttaa elintarvikkeiden arvonlisäverotus, joka on Suomessa kansainvälistä tasoa kireämpi ja selittää siten osaltaan hintaeroa Suomen ja muiden maiden välillä. Elintarvikkeiden kuluttajahintoja määrittävät myös elintarvikeketjun toimialojen tuottajahinnat. Tuottajahintoihin vaikuttavat puolestaan kilpailu ja tuotannon yksikkökustannukset elintarvikeketjun toimialoilla. Tutkimuksen tavoitteena oli selvittää, missä määrin elintarvikkeiden kuluttajahintojen korkeus Suomessa johtuu elintarvikkeiden arvonlisäverotuksen kireyden ohella elintarvikeketjun kilpailun tai kustannuskilpailukyvyn puutteista suhteessa vertailumaihin.

Selvityksen perusteella elintarvikeketjun tuottajahintoja määrittävä kilpailullisuus on Suomen maataloudessa, elintarviketeollisuudessa ja kaupassa suunnilleen vertailumaiden tasolla. Suomen elintarvikekulutuksen hintatason korkeutta ei siten selitä Suomen elintarvikeketjun kilpailun puute suhteessa vertailumaihin. Kilpailun puutteen sijasta Suomen elintarvikekulutuksen hintatason korkeutta suhteessa vertailumaihin selittää pikemminkin kilpailukyvyn puute, eli Suomen elintarvikeketjun korkea kustannustaso uusien EU-maiden ja Yhdysvaltojen kustannustasoon verrattuna. Länsi-Euroopan vanhoihin EU-maihin verrattuna kilpailukykyongelmaa on lähinnä vain maataloudessa.

Keskeinen syy Suomen maatalouden kilpailukykyongelmaan on vertailumaita heikompi tuottavuus, jonka taustalla on muun muassa se, että meillä maataloutta joudutaan harjoittamaan huonommissa luonnonoloissa kuin vertailumaissa. Sen sijaan elintarviketeollisuuden ja kaupan tuottavuus on Suomessa kansainvälisesti vertaillen melko hyvällä tasolla ja keskeinen selittäjä sille, että Suomen elintarviketeollisuus ja kauppa ovat tuottajahinnoilla ja tuotannon yksikkökustannuksilla tarkastellen melko kilpailukykyisiä suhteessa läntisiin teollisuusmaihin. 


\section{Kirjallisuus}

Arovuori, K., Karikallio, H. \& Pyykkönen, P. 2011. Voimasuhteiden kehitys Suomen ruokamarkkinoilla. PTT-raportteja 230.

Kotilainen, M., Koski, H., Mankinen, R. \& Rantala, O. 2010. Elintarvikkeiden hinnanmuodostus ja markkinoiden toimivuus. Elinkeinoelämän Tutkimuslaitos, Keskusteluaiheita No. 1209.

OECD \& Eurostat 2004. Purchasing Power Parities and Real Expenditures - 2002 Benchmark Year.

Timmer, M.P. \& Ypma, G. 2006. Productivity Levels in Distributive Trades: A New ICOP Dataset for OECD Countries. Groningen Growth and Development Centre, University of Groningen, Research Memorandum GD-83.

Timmer, M.P., Ypma, G. \& van Ark, B. 2007. PPPs for Industry Output: A New Dataset for International Comparisons. Groningen Growth and Development Centre, University of Groningen. 